\title{
Convective Drying of Beech Lumber without Color Changes of Wood
}

\section{Konvektivno sušenje bukovih piljenica bez promjene boje drva}

\author{
Original scientific paper • Izvorni znanstveni rad \\ Received-prispjelo: 10. 11. 2011. \\ Accepted-prihvaćeno: 16. 5. 2012. \\ UDK: $630 * 847 ; 674.047 .3 ; 674.031 .12$ \\ doi:10.5552/drind.2012.1135
}

\begin{abstract}
This paper presents the results of analyzing the influence of suggested regimes of chamber drying of beech lumber with the thickness $h=40 \mathrm{~mm}, h=60 \mathrm{~mm}$ and $h=80 \mathrm{~mm}$ from the initial moisture content $W_{p}=70 \%$ to the final moisture content $W_{k}=8 \%$. The regimes ensure the preservation of the natural color of the wood. The study results show that the drying of beech lumber according to the suggested regimes causes no changes in the chromophoric compounds of the wood and the beech lumber preserves its original white-yellow color. Quality parameters of the dried lumber, such as: difference between the average final moisture content and the required final moisture content, and the range of the final moisture and moisture gradient in dried beech lumber, classify this dried lumber into the first quality class. The suggested regimes for drying beech lumber using hot air in the temperature range $t_{s}=37 \div 65{ }^{\circ} \mathrm{C}$ has a negative impact on the duration of the drying process. In comparison with the regimes of beech lumber drying according to ON 490651 , carried out at temperatures $t=60 \div 80{ }^{\circ} \mathrm{C}$, the duration of drying beech lumber with the thickness $h=40 \mathrm{~mm}$ according to the suggested regime is 1.9 times longer, the duration of drying beech lumber with the thickness $h=60 \mathrm{~mm}$ is 2.3 times longer and the duration of drying beech lumber with the thickness $h=80 \mathrm{~mm}$ is 2.9 times longer. The specific heat energy consumption of beech lumber with the initial moisture content $W_{p}=70 \%$ to the final moisture content $W_{k}=8 \%$ in a chamber type $K W C 121$, according to the suggested regimes, is equals to $Q_{T Z N}=514.46 \mathrm{kWh} \cdot \mathrm{m}^{-3}$ for the thickness $h=40 \mathrm{~mm}$, $Q_{T Z N}=557.62 \mathrm{kWh} \cdot \mathrm{m}^{-3}$ for lumber with the thickness $h=60 \mathrm{~mm}$, and $Q_{T Z N}=643.16 \mathrm{kWh} \cdot \mathrm{m}^{-3}$ for lumber with the thickness $h=80 \mathrm{~mm}$. The specific heat energy consumption needed for the drying of $1 \mathrm{~m}^{3}$ of beech lumber with the thickness $h=60 \mathrm{~mm}$ according to the suggested regime is by 26.89\% higher than the specific heat energy consumption used to dry beech lumber of the same thickness according to the regime of beech lumber drying by Vzduchotechnika a.s. which does not preserve the natural color of the wood.
\end{abstract}

Keywords: beech lumber, convective drying, regime of drying, color of wood

SAŽETAK • U radu se prezentiraju rezultati analize utjecaja predloženih režima sušenja bukovih piljenica debljine $h=40 \mathrm{~mm}, h=60 \mathrm{~mm}$ i $h=80 \mathrm{~mm}$ od početnog sadržaja vodet $W_{p}=70 \%$ do konačnog sadržaja vode $W_{k}=8 \%$ u komornim sušionicama. Predloženi režimi osiguravaju zadržavanje prirodne boje drva. Rezultati studije pokazuju da sušenje bukova drva prema predloženim rě̌imima sušenja ne uzrokuje promjene kromoforičnih sastojaka drva pa bukove piljenice zadržavaju svoju originalnu bijeložutu boju. Parametri kvalitete osušenog drva kao što su razlika između prosječnoga konačnog sadržaja vode i traženoga konačnog sadržaja vode, raspon konačnih

\footnotetext{
${ }^{1}$ Author is professor at Faculty of Wood Sciences and Technology, Technical University in Zvolen, Zvolen, Slovak Republic. ${ }^{2}$ Author is professor at Faculty of Forest Industry, University of Forestry, Sofia, Bulgaria.

Autor je profesor Fakulteta za znanost o drvu i tehnologiju Tehničkog sveučilišta u Zvolenu, Zvolen, Republika Slovačka. ${ }^{2}$ Autor je profesor Fakulteta šumske industrije Šumarskog sveučilišta, Sofija, Bugarska.
} 
sadržaja vode te gradijent vlažnosti osušenih bukovih piljenica svrstavaju piljenice osušene predloženim režimom u I. stupanj kvalitete. Provedba predloženih režima sušenja bukovih piljenica upotrebom vrućeg zraka temperature u rasponu $37-65^{\circ} \mathrm{C}$ ima negativan utjecaj na trajanje procesa sušenja. U usporedbi s režimima sušenja bukovih piljenica prema standardu ON 49 0651, koji se provode pri temperaturama $60-80^{\circ} \mathrm{C}$, trajanje procesa sušenja bukovih piljenica debljine $40 \mathrm{~mm}$ predloženim je rě̌imom 1,9 puta dulje, za piljenice debljine $60 \mathrm{~mm}$ proces sušenja traje 2,3 puta dulje, a za piljenice debljine $80 \mathrm{~mm}$ 2,9 puta dulje. Specifična potrošnja toplinske energije za sušenje bukovih piljenica predloženim režimom sušenja s početnog sadržaja vode 70 \% na konačni sadržaj vode 8 $\%$ u komori tipa KWC 121 iznosi $Q_{T Z N}=514,46 \mathrm{kWh} \cdot \mathrm{m}^{-3}$ za piljenice debljine $\mathrm{h}=40 \mathrm{~mm}, Q_{T Z N}=557,62 \mathrm{kWh} \cdot \mathrm{m}^{-3}$ za piljenice debljine $h=60 \mathrm{~mm}$, te $Q_{T Z N}=643,16 \mathrm{kWh} \cdot \mathrm{m}^{-3}$ za piljenice debljine $h=80 \mathrm{~mm}$. Specifična je potrošnja toplinske energije potrebna za sušenje $1 \mathrm{~m}^{3}$ bukovih piljenica debljine $h=60 \mathrm{~mm}$ primjenom predloženih režima sušenja 26,89 \% veća od specifične potrošnje toplinske energije za sušenje bukovih piljenica jednake debljine prema režimu sušenja bukovih piljenica koju primjenjuje Vzduchotechnika a.s., a koja nije usmjerena na očuvanje prirodne boje drva.

Ključne riječi: bukove piljenice, konvektivno sušenje, režim sušenja, boja drva

\section{INTRODUCTION 1. UVOD}

Wood drying belongs to the basic technological operations of wood processing. This technological process is based on considerably complicated hydro-thermal process and despite the noticeable effort of scientists and technologists, it is not yet fully clarified.

The drying of beech lumber carried out in chambers according to the regimes of the companies: Hildebrandt $\mathrm{GmbH}$, Incomac S.R.L., Vzduchotechnika a.s., and Mühlböck GmbH is commonly realized at temperatures $t=60-80^{\circ} \mathrm{C}$. In beech wood, the hydro-thermal process at these temperatures not only removes water from the wood, but also develops some chemical reactions such as partial hydrolysis of the hemicelluloses and the extraction of water-soluble substances (Bučko, 1995; Trebula and Bučko, 1996; Halaj, 1999; Dzurenda and Deliiski, 2000; Kačík, 2001; Laurova et al, 2004), which cause irreversible color changes of wood. One such change is from the original white-yellow color of the beech wood to a dull brown-pink shade. The extent of the change of wood color during the hydro-thermal treatment of wood, Deliiski (1991) is defined by the criterion of color homogenization of wood $S_{\mathrm{FH}}$, which is equal to the integral area of the function of temperature change during the hydro-thermal treatment of wood. The unit of this criterion is a thermosecond $(\mathrm{K} \cdot \mathrm{s})$. The change of the color shade of beech wood from the original white-yellow to brown-pink shade occurs after surpassing the limit for the color homogenization criterion $S_{\mathrm{FH}} \leq 1.2 \times 10^{7} \mathrm{~K} \cdot \mathrm{s}$ (Deliiski, 2003).

To eliminate this imperfection, special regimes were created for convective drying of beech wood in chambers, which preserve the natural color of the beech wood. The goal of this work is to present the suggested regimes for drying beech lumber with the thickness $h=$ $40 \mathrm{~mm}, h=60 \mathrm{~mm}$ and $h=80 \mathrm{~mm}$, from $W_{\mathrm{p}}=70 \%$ to $W_{\mathrm{k}}=8 \%$, in chambers and their evaluation from the aspects of quality of dried lumber, extent of color change (Deliiski and Dzurenda, 2003) and their specific heat consumption.

\section{MATERIAL AND METHODS 2. MATERIJAL I METODE}

The parameters of the regimes for drying beech lumber with the thickness $h=40 \mathrm{~mm}, h=60 \mathrm{~mm}$ and $h=80 \mathrm{~mm}$, from $W_{\mathrm{p}}=70 \%$ to $W_{\mathrm{k}}=8 \%$, which cause no change of the natural color of the wood, are shown in Table 1.

At the end of lumber drying, when the wood moisture content reaches a value of approximately $20 \%$, conditioning is included for partial decreasing of the moisture gradient. Conditioning is carried out by an increase of the relative humidity.

The drying of beech lumber with the thickness $h$ $=40 \mathrm{~mm}, h=60 \mathrm{~mm}$ and $h=80 \mathrm{~mm}$, according to individual regimes, was carried out in chamber type KWC 121 manufactured by Vzduchotechnika a.s. Nové Mesto nad Váhom.

The quality of the drying process of beech lumber is evaluated by drying gradient $U$ defined as the quotient of the average moisture content of the lumber subjected to drying and equilibrium moisture content throughout the process.

After the completion of the drying process, a quality check of the dried lumber was performed on 8 samples with the determination of the following parameters: difference between the average final moisture content and the required final moisture content, fluctuation of the final moisture content, moisture gradient, and change of wood color.

The difference $w_{0}$ between the average final moisture content and the required final moisture content (in $\%$ ) was quantified using the following equation:

$$
W_{0}=\frac{\sum_{i=1}^{n} W_{\mathrm{ik}}}{n}-W_{\mathrm{k}},
$$

where:

$n$ - number of samples / broj uzoraka

$W_{\mathrm{ik}}$ - average final moisture content of samples / prosječni konačni sadržaj vode u uzorcima, \%;

$W_{\mathrm{k}}$ - required final moisture content of samples / potrebni konačni sadržaj vode u uzorcima, \%. 
Table 1 Parameters of the regimes for drying beech lumber from $W_{\mathrm{p}}=70 \%$ to $W_{\mathrm{k}}=8 \%$, preserving the original wood color, depending on the lumber thickness

Tablica 1. Parametri režima sušenja bukovih piljenica od $W_{\mathrm{p}}=70 \%$ do $W_{\mathrm{k}}=8 \%$, koji omogućuju očuvanje prirodne boje drva, ovisno o debljini piljenica

\begin{tabular}{|l|c|c|c|c|c|c|c|c|c|}
\hline \multirow{2}{*}{ Lumber thickness / Debljina piljenica } & \multicolumn{3}{|c|}{$h=40 \mathrm{~mm}$} & \multicolumn{3}{c|}{$h=60 \mathrm{~mm}$} & \multicolumn{3}{c|}{$h=80 \mathrm{~mm}$} \\
\hline & $t$ & $\Delta t$ & $\tau$ & $t$ & $\Delta t$ & $\tau$ & $t$ & $\Delta t$ & $\tau$ \\
\cline { 2 - 11 } & ${ }^{\circ} \mathrm{C}$ & ${ }^{\circ} \mathrm{C}$ & $\mathrm{h}$ & ${ }^{\circ} \mathrm{C}$ & ${ }^{\circ} \mathrm{C}$ & $\mathrm{h}$ & ${ }^{\circ} \mathrm{C}$ & ${ }^{\circ} \mathrm{C}$ & $\mathrm{h}$ \\
\hline Initial heating / Početno zagrijavanje & 43 & 3 & 5 & 42 & 3 & 8 & 41 & 3 & 12 \\
\hline $70-45$ & 38 & 5 & 77 & 37 & 5 & 133 & 37 & 5 & 228 \\
\hline $45-35$ & 40 & 5.5 & 29 & 39 & 5 & 82 & 39 & 4.5 & 143 \\
\hline $35-25$ & 44 & 7.5 & 72 & 43 & 7 & 123 & 42 & 6.5 & 217 \\
\hline $25-20$ & 48 & 9.5 & 55 & 47 & 9 & 97 & 46 & 8.5 & 166 \\
\hline Conditioning / Kondicioniranje & 48 & 5.5 & 4 & 47 & 5 & 6 & 46 & 4.5 & 9 \\
\hline $20-15$ & 54 & 14 & 64 & 53 & 13.5 & 109 & 52 & 13.5 & 189 \\
\hline $15-10$ & 61 & 18.5 & 88 & 60 & 18 & 152 & 59 & 17.5 & 263 \\
\hline $10-8$ & 64 & 23 & 42 & 63 & 20 & 71 & 63 & 19 & 124 \\
\hline Treatment / Tretiranje & 64 & 6 & 9 & 63 & 5.5 & 13 & 63 & 5.5 & 18 \\
\hline Cooling / Hlađenje & & & 5 & & & 8 & & & 12 \\
\hline
\end{tabular}

The range of final moisture content of the dried lumber was calculated as the difference between maximum and minimum values of the moisture content in dried samples according to the equation:

$$
W_{\mathrm{k} 0}=W_{\max }-W_{\min }
$$

where:

$W_{\max }$ - maximum moisture content in samples / najveć $i$ sadržaj vode u uzorcima, \%;

$W_{\min }$ - minimum moisture content in samples / najmanji sadržaj vode u uzorcima, $\%$.

The moisture gradient $\Delta W$ (in \%) was calculated as the difference between the moisture content of the middle layer of the samples and the average moisture content of both surface layers:

$$
\Delta W=W_{\mathrm{c}}-W_{\text {pov }},
$$

where:

$W_{c}$ - moisture content of the sample middle layer / sadržaj vode u srednjem sloju uzoraka, \%;

$W_{\text {pov }}$ - moisture content of the sample surface layers / sadržaj vode na površini uzoraka, \%.

The color of wood on the surface of beech lumber was measured by a colorimeter Color Reader CR10 , which determines the color by a set of values in the color coordinate system CIE $-L^{*} a * b$. The principle of measuring with this colorimeter is based on the determination of the following parameters: $L^{*}$, which quantifies the lightness of the color from 100 for white color to 0 for black; $a^{*}$, which quantifies the chromatic coordinate of color shade between red and green; $b^{*}$, which quantifies the chromatic coordinate of color shade between yellow and blue.

The change of the color of beech wood subjected to drying was determined by the size of changes of the individual coordinates in the color coordinate system before drying and also on a planed surface of wood after drying as well as by the size of color deviation $\Delta E_{\text {a.b }}$ according to CIE (1986), presented by the equation:

$$
\Delta E_{a b}=\sqrt{\left(L_{2}^{*}-L_{1}^{*}\right)^{2}+\left(a_{2}^{*}-a_{1}^{*}\right)^{2}+\left(b_{2}^{*}-b_{1}^{*}\right)^{2}},
$$

where:

$L^{*}$ - color lightness / svjetlina boje;

$a^{*}$ - coordinate of color shade between red and green / koordinata nijanse boje izmedu crvene i zelene;

$b^{*}$ - coordinate of color shade between yellow and blue / koordinata nijanse boje između žute i plave.

$L_{1}^{*}, a_{1}^{*}, b_{1}^{*}$ represent the values before drying and $L_{2}^{*}, a_{2}^{*}, b_{2}^{*}$ represent the values after drying.

The specific heat consumption required for drying beech lumber with the thickness $h=40 \mathrm{~mm}, h=60 \mathrm{~mm}$ and $h=80 \mathrm{~mm}$ in chamber type KWC 121 according to the suggested regimes is determined as technically reasonable norms $\left(Q_{\mathrm{TZN}}\right)$ via a mathematical model for technical calculation of normative heat consumption for lumber drying in chambers (Dzurenda and Deliiski, 2009). The normative specific heat energy consumption (in $\mathrm{kWh} \cdot \mathrm{m}^{-3}$ ) for lumber drying in chambers is presented by the equation:

$$
Q_{\mathrm{TZN}}=\frac{Q_{\mathrm{W}}+Q_{\mathrm{V}}+Q_{\mathrm{A}}+Q_{\mathrm{L}}+Q_{\mathrm{HG}}+Q_{\mathrm{S}}}{V_{\mathrm{D}}}
$$

where:

$Q_{\mathrm{W}}$ - heat energy, necessary for the heating of lumber in chambers / toplinska energija za zagrijavanje piljenica, kWh;

$Q_{\mathrm{V}}$ - heat energy, necessary for the heating of wet air in the drying chamber and its moistening during the phase of heating and final treatment / toplinska energija za zagrijavanje vlažnog zraka u sušionici tijekom faze inicijalnog zagrijavanja, kondicioniranja i obrade, $\mathrm{kWh}$; $Q_{\mathrm{A}}$ - heat energy, necessary for the heating of the construction of drying chambers / toplinska energija za zagrijavanje konstrukcije sušionice, $\mathrm{kWh}$;

$Q_{\mathrm{L}}$ - heat energy, necessary for the heating of air in the drying chamber for the purpose of water evaporation from wood / toplinska energija za zagrijavanje zraka u sušionici radi isparavanja vode iz drva, $\mathrm{kWh}$; $Q_{\mathrm{HG}}$ - heat energy, necessary for the release of hygroscopically bounded water from wood / toplinska energija za oslobađanje higroskopski vezane vode iz drva, $\mathrm{kWh}$; $Q_{\mathrm{S}}$ - heat energy, necessary for the covering of heat losses of the drying chamber / toplinska energija za nadoknadu gubitaka topline sušionice, $\mathrm{kWh}$; 


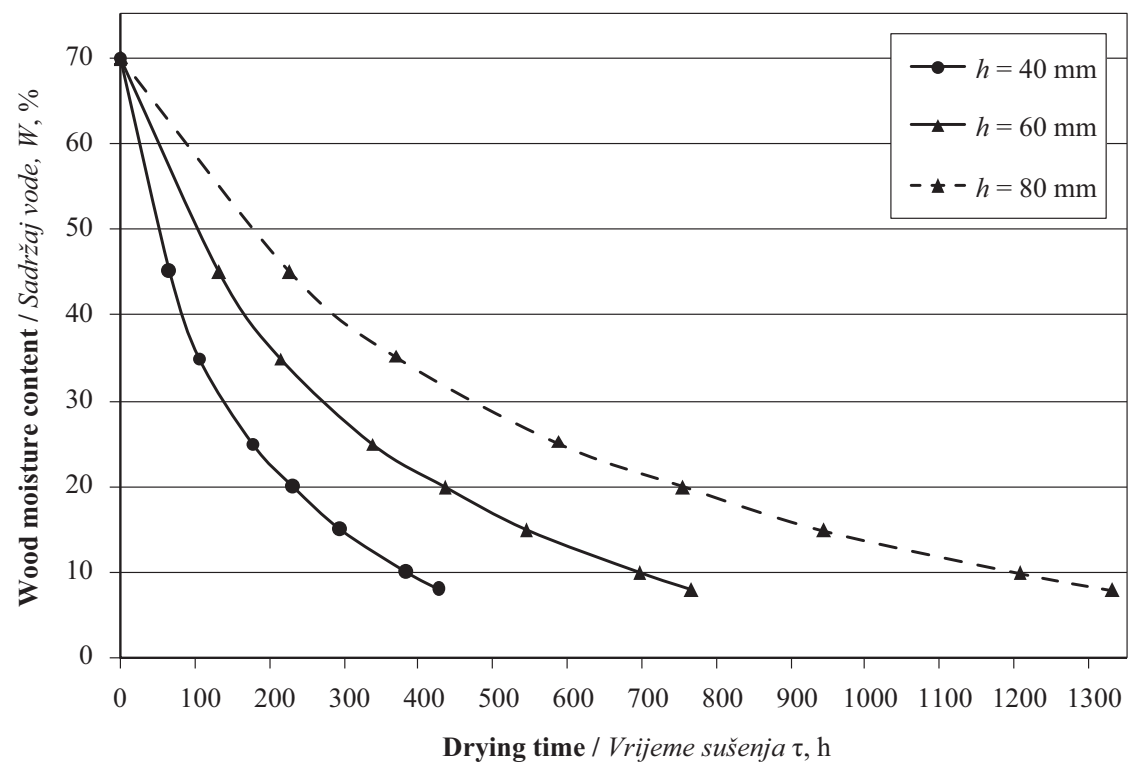

Figure 1 Change in the average moisture content of the lumber during the suggested regimes, depending on the thickness $h$ Slika 1. Promjena prosječnog sadržaja vode u piljenicama tijekom sušenja predloženim režimima, ovisno o debljini piljenica

$V_{\mathrm{D}}$ - volume of wood subjected to drying / obujam drva koje se suši, $\mathrm{m}^{3}$.

\section{RESULTS}

3. REZULTATI

The change in the average moisture content of the lumber with the thickness $h=40 \mathrm{~mm}, h=60 \mathrm{~mm}$ and $h=80 \mathrm{~mm}$ during the suggested drying regimes is shown in Fig.1

The change in the drying gradient of the suggested regimes depending on the phase of the regime and on lumber thickness shown in Fig. 2.

The initial and final moisture content of the dried samples, the values of the parameters of color coordinates $L^{*}, a^{*}$, and $b^{*}$ of dried samples before and after drying, as well as the size of color deviations of beech wood $\Delta E_{a b}$ caused by the drying process are shown in Tables 2, 3 and 4 .
Table 5 shows the results of the analysis, by which the quality was evaluated of dried beech lumber based on the difference between the average final moisture content and the required final moisture content, fluctuation in the final moisture content and moisture gradient of lumber.

Based on the comparison of the measured values of deviations of the average final moisture content from the required final moisture content, the range of the final moisture content of the dried beech lumber and the moisture gradient in the dried lumber with the values of quality characteristics of individual quality classes, it can be concluded that the dried beech lumber with the thickness $h=40 \mathrm{~mm}$ fulfills the criteria of the first quality class according to the analysis of the following quality characteristics: $W_{0}=0.3 \% \leq 0.5 \%, W_{\mathrm{k} 0}=1.0$ $\% \leq 2.0 \%$ a $\Delta W=0.8 \div 1.3 \% \leq 1.5 \%$.

Analogously, the quality evaluation of the dried beech lumber with the thickness $h=60 \mathrm{~mm}$ with the quality

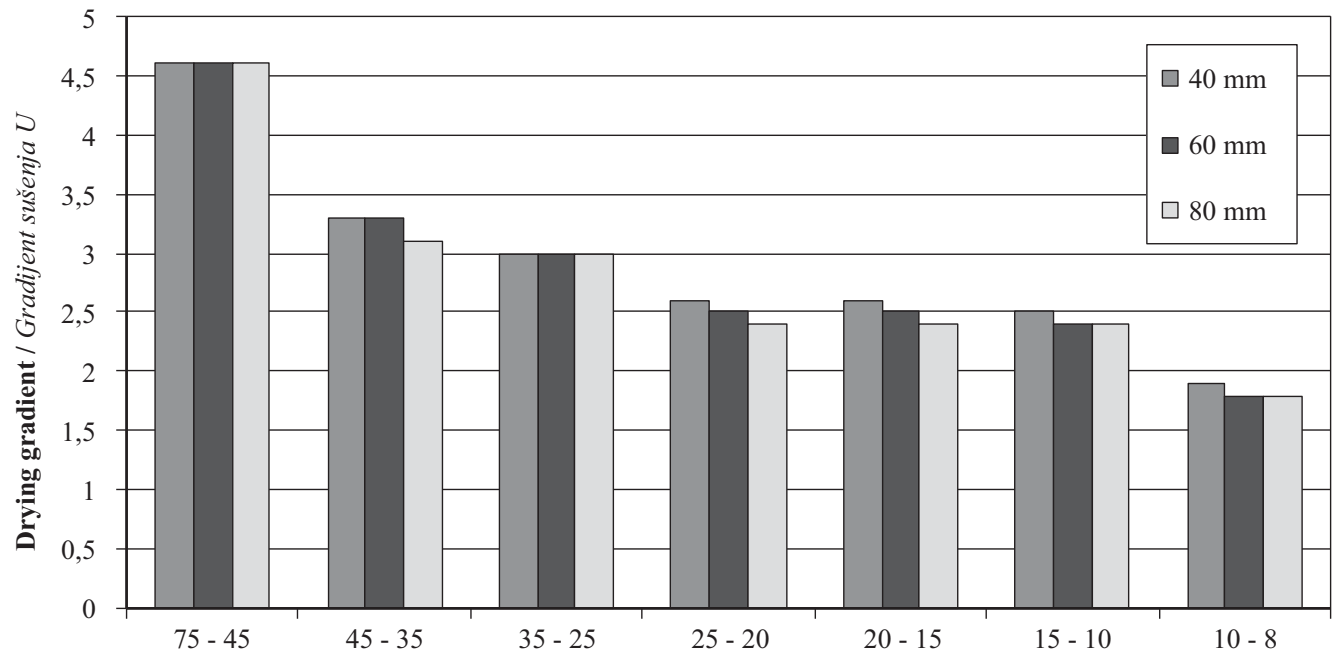

Wood moisture content / Sadržaj vode $W, \%$

Figure 2 Change in the drying gradient of the suggested regimes depending on wood moisture content and lumber thickness Slika 2. Promjena gradijenta sušenja za predložene režime sušenja ovisno o sadržaju vode i debljini piljenica 
Table 2 Changes in moisture content, color coordinates $L^{*}, a^{*}$, and $b^{*}$ of beech lumber with the thickness $h=40 \mathrm{~mm}$ at the beginning and at the end of drying, and the size of color deviation of wood $\Delta E_{a b}$ during the drying process

Tablica 2. Promjene sadržaja vode, koordinata boje $L^{*}, a^{*}$ i $b^{*}$ za bukove piljenice debljine $h=40 \mathrm{~mm}$ na početku i na kraju sušenja te veličina promjene boje $\Delta E_{a b}$ tijekom procesa sušenja

\begin{tabular}{|c|c|c|c|c|c|}
\hline \multirow{2}{*}{$\begin{array}{l}\text { Sample } \\
\text { Uzorak }\end{array}$} & \multirow{2}{*}{$\begin{array}{l}\text { Moisture content of lumber } \\
\text { Sadržaj vode u piljenicama }\end{array}$} & \multicolumn{3}{|c|}{ Color coordinates / Koordinate boje } & \multirow{2}{*}{$\Delta \mathrm{E}_{\mathrm{ab}}$} \\
\hline & & $L^{*}$ & $a^{*}$ & $b^{*}$ & \\
\hline \multirow{2}{*}{1} & $W_{\mathrm{p}}=70.3 \%$ & 71.8 & 9.2 & 21.9 & \multirow{3}{*}{0.9} \\
\hline & $W_{\mathrm{k}}=7.9 \%$ & 72.3 & 8.8 & 22.6 & \\
\hline \multicolumn{2}{|c|}{ Change of color coordinates / Promjena koordinata boje } & 0.5 & -0.4 & 0.7 & \\
\hline \multirow{2}{*}{2} & $W_{\mathrm{p}}=71.6 \%$ & 70.7 & 9.1 & 21.6 & \multirow{3}{*}{1.0} \\
\hline & $W_{\mathrm{k}}=8.3 \%$ & 71.3 & 8.8 & 22.4 & \\
\hline \multicolumn{2}{|c|}{ Change of color coordinates / Promjena koordinata boje } & 0.6 & -0.3 & 0.8 & \\
\hline \multirow{2}{*}{3} & $W_{\mathrm{p}}=70.8 \%$ & 68.5 & 14.1 & 28.6 & \multirow{3}{*}{1.3} \\
\hline & $W_{\mathrm{k}}=8.2 \%$ & 69.4 & 13.5 & 29.3 & \\
\hline \multicolumn{2}{|c|}{ Change of color coordinates / Promjena koordinata boje } & 0.9 & -0.6 & 0.7 & \\
\hline \multirow{2}{*}{4} & $W_{\mathrm{p}}=73.2 \%$ & 70.8 & 10.0 & 22.6 & \multirow{3}{*}{1.3} \\
\hline & $W_{\mathrm{k}}=8.9 \%$ & 71.2 & 9,1 & 23.4 & \\
\hline \multicolumn{2}{|c|}{ Change of color coordinates / Promjena koordinata boje } & 0.4 & -0.9 & 0.8 & \\
\hline \multirow{2}{*}{5} & $W_{\mathrm{p}}=72.5 \%$ & 69.6 & 11.2 & 24.8 & \multirow{3}{*}{1.1} \\
\hline & $W_{\mathrm{k}}=8.6 \%$ & 70.3 & 10.5 & 25.2 & \\
\hline \multicolumn{2}{|c|}{ Change of color coordinates / Promjena koordinata boje } & 0.7 & -0.7 & 0.4 & \\
\hline \multirow{2}{*}{6} & $W_{\mathrm{p}}=70.5 \%$ & 72.1 & 9.6 & 23,7 & \multirow{3}{*}{1.4} \\
\hline & $W_{\mathrm{k}}=8.0 \%$ & 72.7 & 8.7 & 24.6 & \\
\hline \multicolumn{2}{|c|}{ Change of color coordinates / Promjena koordinata boje } & 0.6 & -0.9 & 0.9 & \\
\hline \multirow{2}{*}{7} & $W_{\mathrm{p}}=71.8 \%$ & 69.8 & 11.7 & 25.8 & \multirow{3}{*}{1.2} \\
\hline & $W_{\mathrm{k}}=8.4 \%$ & 70.6 & 11.0 & 26.4 & \\
\hline \multicolumn{2}{|c|}{ Change of color coordinates / Promjena koordinata boje } & 0.8 & -0.7 & 0.6 & \\
\hline \multirow{2}{*}{8} & $W_{\mathrm{p}}=71.2 \%$ & 66.8 & 11.0 & 22.1 & \multirow{3}{*}{1.0} \\
\hline & $W_{\mathrm{k}}=8.1 \%$ & 67.4 & 10.5 & 22.8 & \\
\hline \multicolumn{2}{|c|}{ Change of color coordinates / Promjena koordinata boje } & 0.6 & -0.5 & 0.7 & \\
\hline
\end{tabular}

characteristics $W_{0}=0.4 \% \leq 0.5 \%, W_{\mathrm{k} 0}=1.5 \% \leq 2.0 \% \mathrm{a}$ $\Delta W=0.6 \div 2.3 \% \leq 2.5 \%$, as well as the dried beech lumber with the thickness $h=80 \mathrm{~mm}$ with the quality characteristics $W_{0}=0.4 \% \leq 0.5 \%, W_{\mathrm{k} 0}=1.3 \% \leq 2.0 \%$ a $\Delta W=1.8 \div 2.3 \% \leq 2.4 \%$, fulfill the criteria for placing the dried beech lumber into the first quality class.

During the drying process, the color coordinates of dried samples of beech lumber with the thickness $h$ $=40 \mathrm{~mm}$, as well as $h=60 \mathrm{~mm}$ and $h=80 \mathrm{~mm}$ have shown slight differences in the form of increasing the whiteness of the beech wood by $\Delta L^{*}=0.4 \div 1.2$, decreasing of coordinate $a^{*}$, which describes the range of color shades between red and green color by $\Delta a^{*}=0.3$ $\div 1.3$ and an increasing of coordinate $b^{*}$, which describes the range of color shades between yellow and blue color by $\Delta b^{*}=0.1 \div 0.9$.

The total changes of color differences of beech wood in the drying process $\Delta E_{a b}=0.8 \div 1.6$ belong to the interval of color difference $\Delta E_{a b} \leq 2$, also marked as "inconsiderable changes of the color".

Table 7 illustrates the values of the total specific heat energy consumptions and the heat energy consumptions of individual items of the balance of the drying process of lumber with the thickness $h=60 \mathrm{~mm}$, according to the suggested regime and the regime for drying beech lumber of Vzduchotechnika a.s. in chamber type
KWC 121 from moisture content $W_{\mathrm{p}}=70 \%$ to $W_{\mathrm{k}}=8 \%$, at initial temperature of the wood $t_{\mathrm{d}}^{\mathrm{p}}=10^{\circ} \mathrm{C}$ and the average air temperature near the drying chamber $t_{\mathrm{o}}=10^{\circ} \mathrm{C}$.

\section{DISCUSSION}

\section{RASPRAVA}

According to the specification of the temperatures and psychrometric differences of the drying air in the suggested regimes of convective drying of beech lumber in chambers, according to the categorization of drying regimes (Kollmann, 1955; Trebula, 1989) these regimes are classified to the so-called regimes with rising temperature and decreasing relative humidity of the drying environment.

From the range of values of the drying gradient $U$ $=4.6 \div 3.3$, during the drying of beech lumber with the thickness $h=40 \mathrm{~mm}$ and $h=60 \mathrm{~mm}$, it can be concluded that from the beginning of the drying to reaching the average moisture content $W=35 \%$, despite low temperature of the drying air, the drying regime can be considered as hard with the probability of creating a moisture gradient along the lumber section. A similar statement also applies to the drying gradient $U=4.6 \div$ 3.1 during the drying of beech lumber with the thickness $h=80 \mathrm{~mm}$. 
Table 3 Changes in moisture content, color coordinates $L^{*}, a^{*}$, and $b^{*}$ of beech lumber with the thickness $h=60 \mathrm{~mm}$ at the beginning and at the end of drying, and the size of color deviation of wood $\Delta E_{a b}$ during the drying process

Tablica 3. Promjene sadržaja vode, koordinata boje $L^{*}, a^{*}$ i $b^{*}$ za bukove piljenice debljine $h=60 \mathrm{~mm}$ na početku i na kraju sušenja te veličina promjene boje $\Delta E_{a b}$ tijekom procesa sušenja

\begin{tabular}{|c|c|c|c|c|c|}
\hline \multirow{2}{*}{$\begin{array}{l}\text { Sample } \\
\text { Uzorak }\end{array}$} & \multirow{2}{*}{$\begin{array}{l}\text { Moisture content of lumber } \\
\text { Sadržaj vode u piljenicama }\end{array}$} & \multicolumn{3}{|c|}{ Color coordinates / Koordinate boje } & \multirow{2}{*}{$\Delta \mathrm{E}_{\mathrm{ab}}$} \\
\hline & & $L^{*}$ & $a^{*}$ & $b^{*}$ & \\
\hline \multirow[t]{2}{*}{1} & $W_{\mathrm{p}}=70.9 \%$ & 69.2 & 11.2 & 25.2 & \multirow[t]{3}{*}{1.2} \\
\hline & $W_{\mathrm{k}}=8.5 \%$ & 69.8 & 10.2 & 25.3 & \\
\hline \multicolumn{2}{|c|}{ Change of color coordinates / Promjena koordinata boje } & 0.6 & -1.0 & 0.1 & \\
\hline \multirow[t]{2}{*}{2} & $W_{\mathrm{p}}=71.8 \%$ & 70.8 & 8.7 & 21.8 & \multirow[t]{3}{*}{0.9} \\
\hline & $W_{\mathrm{k}}=9.2 \%$ & 71.1 & 8.3 & 22.6 & \\
\hline \multicolumn{2}{|c|}{ Change of color coordinates / Promjena koordinata boje } & 0.3 & -0.4 & 0.8 & \\
\hline 3 & $W_{\mathrm{p}}=69.1 \%$ & 72.1 & 9.6 & 25.3 & \multirow[t]{3}{*}{1.3} \\
\hline & $W_{\mathrm{k}}=7.7 \%$ & 72.7 & 8.8 & 26.1 & \\
\hline \multicolumn{2}{|c|}{ Change of color coordinates / Promjena koordinata boje } & 0.6 & -0.8 & 0.8 & \\
\hline 4 & $W_{\mathrm{p}}=70.8 \%$ & 69.4 & 10.5 & 22.8 & \multirow[t]{3}{*}{1.3} \\
\hline & $W_{\mathrm{k}}=8.6 \%$ & 70.2 & 9.9 & 23.6 & \\
\hline \multicolumn{2}{|c|}{ Change of color coordinates / Promjena koordinata boje } & 0.8 & -0.6 & 0.8 & \\
\hline 5 & $W_{\mathrm{p}}=70.7 \%$ & 69.9 & 9.2 & 22.3 & \multirow[t]{3}{*}{1.4} \\
\hline & $W_{\mathrm{k}}=8.4 \%$ & 71.1 & 8.6 & 22.8 & \\
\hline \multicolumn{2}{|c|}{ Change of color coordinates / Promjena koordinata boje } & 1.2 & -0.6 & 0.5 & \\
\hline 6 & $W_{\mathrm{p}}=70.7 \%$ & 72.2 & 10.1 & 26.0 & \multirow[t]{3}{*}{1.1} \\
\hline & $W_{\mathrm{k}}=8.2 \%$ & 72.7 & 9.6 & 26.8 & \\
\hline \multicolumn{2}{|c|}{ Change of color coordinates / Promjena koordinata boje } & 0.5 & -0.5 & 0.8 & \\
\hline 7 & $W_{\mathrm{p}}=71.1 \%$ & 69.6 & 11.0 & 21.7 & \multirow[t]{3}{*}{1.1} \\
\hline & $W_{\mathrm{k}}=8.4 \%$ & 70.2 & 10.3 & 22.3 & \\
\hline \multicolumn{2}{|c|}{ Change of color coordinates / Promjena koordinata boje } & 0.6 & -0.7 & 0.6 & \\
\hline 8 & $W_{\mathrm{p}}=70.8 \%$ & 64.5 & 11.6 & 24.8 & \multirow[t]{3}{*}{1.3} \\
\hline & $W_{\mathrm{k}}=8.3 \%$ & 65.3 & 10.9 & 25.1 & \\
\hline \multicolumn{2}{|c|}{ Change of color coordinates / Promjena koordinata boje } & 0.8 & -0.7 & 0.3 & \\
\hline
\end{tabular}

From the average moisture content $W=35 \%$ up to the end of the drying process, the parameters of the drying medium ensure a finer drying of beech lumber. Despite this, the goal of the authors to suggest drying regimes that cause no change in the color of beech lumber while reaching the topmost quality of dried material is validated by the results of the qualitative checks made at the end of drying. According to the results of these checks, the beech lumber dried in chamber type KWC 121 had the natural white-yellow color and the moisture gradient $\Delta W \leq 0.8 \div 1.3 \%$ for lumber with the thickness $h=40 \mathrm{~mm}, \Delta W \leq 0.6 \div 2.3 \%$ for lumber with $h=60$ $\mathrm{mm}$, and $\Delta W \leq 1.8 \div 2.4 \%$ for lumber with $h=80 \mathrm{~mm}$.

The difference between the suggested regimes and the classical regimes for convective beech lumber drying in chambers developed by the companies Hildebrandt GmbH, Incomac S.R.L., Vzduchotechnika a.s., Mühlböck GmbH (carried out at temperatures $t=60 \div$ $80{ }^{\circ} \mathrm{C}$ and allowing color change of beech lumber to brown-pink) is that the process of drying beech lumber according to the suggested regimes is carried out at temperatures within the lower temperature range of the classical regimes.

During the removal of free water located in the lumens of beech wood cells, the drying is carried out by hot air with temperature lower than $t=50^{\circ} \mathrm{C}$ and psychrometric difference $\Delta t=5 \div 10{ }^{\circ} \mathrm{C}$ so that the temperature of the cell walls and free water in the lumens do not exceed $t_{\mathrm{m}} \leq 40^{\circ} \mathrm{C}$. At these temperatures, the conditions for the process of deacetylation of beech wood, and for subsequent hydrolytical solution of polysaccharidic and extractive substances of beech lumber, which cause changes in the chromophoric structure of wood, cannot be fulfilled (Trebula and Bučko, 1996).

The increase of the temperature of the drying medium to $t=53 \div 65{ }^{\circ} \mathrm{C}$ and the temperature of the wet wood over $t_{\mathrm{m}} \geq 40{ }^{\circ} \mathrm{C}$ are achieved when the average moisture content $W \leq 20 \%$. Then due to the absence of free water in the wood, the increased temperature of the drying air does not cause a change in the chromophoric structure of beech wood. This statement is validated by the results of the measuring of changes of beech wood color caused by drying, as well as by the results of works by Klement and Smilek (2010) and Klement et al. (2011), who analyzed the influence of the temperature and the method of drying of beech wood on the color shade of the dried beech wood.

The drying process of beech lumber at the lower temperatures compared to the classical regimes for convective drying of beech lumber is characterized by a lon- 
Table 4 Changes in moisture content, color coordinates $L^{*}, a^{*}$, and $b^{*}$ of beech lumber with the thickness $h=80 \mathrm{~mm}$ at the beginning and at the end of drying, and the size of color deviation of wood $\Delta E_{a b}$ during the drying process

Tablica 4. Promjene sadržaja vode, koordinata boje $L^{*}, a^{*}$ i $b^{*}$ za bukove piljenice debljine $h=80 \mathrm{~mm}$ na početku i na kraju sušenja te veličina promjene boje $\Delta E_{a b}$ tijekom procesa sušenja

\begin{tabular}{|c|c|c|c|c|c|}
\hline \multirow{2}{*}{$\begin{array}{l}\text { Sample } \\
\text { Uzorak }\end{array}$} & \multirow{2}{*}{$\begin{array}{l}\text { Moisture content of lumber } \\
\text { Sadržaj vode u piljenicama }\end{array}$} & \multicolumn{3}{|c|}{ Color coordinates / Koordinate boje } & \multirow[t]{2}{*}{$\Delta E_{\mathrm{ab}}$} \\
\hline & & $L^{*}$ & $a^{*}$ & $b^{*}$ & \\
\hline \multirow[t]{2}{*}{1} & $W_{\mathrm{p}}=72.9 \%$ & 69.4 & 11.4 & 25.2 & \multirow[t]{3}{*}{1.6} \\
\hline & $W_{\mathrm{k}}=9.2 \%$ & 70.2 & 10.1 & 25.8 & \\
\hline \multicolumn{2}{|c|}{ Change of color coordinates / Promjena koordinata boje } & 0.8 & -1.3 & 0.6 & \\
\hline 2 & $W_{\mathrm{p}}=71.6 \%$ & 70.9 & 8.5 & 21.8 & \multirow[t]{3}{*}{0.8} \\
\hline & $W_{\mathrm{k}}=8.4 \%$ & 71.4 & 8.1 & 22.3 & \\
\hline \multicolumn{2}{|c|}{ Change of color coordinates / Promjena koordinata boje } & 0.5 & -0.4 & 0.5 & \\
\hline 3 & $W_{\mathrm{p}}=69.5 \%$ & 72.2 & 8.8 & 23.3 & \multirow[t]{3}{*}{1.3} \\
\hline & $W_{\mathrm{k}}=7.9 \%$ & 72.9 & 8.2 & 24.1 & \\
\hline \multicolumn{2}{|c|}{ Change of color coordinates / Promjena koordinata boje } & 0.7 & -0.8 & 0.8 & \\
\hline 4 & $W_{\mathrm{p}}=70.8 \%$ & 69.6 & 9.5 & 21.8 & \multirow[t]{3}{*}{1.2} \\
\hline & $W_{\mathrm{k}}=8.6 \%$ & 70.2 & 8.9 & 22.6 & \\
\hline \multicolumn{2}{|c|}{ Change of color coordinates / Promjena koordinata boje } & 0.6 & -0.6 & 0.8 & \\
\hline 5 & $W_{\mathrm{p}}=71.2 \%$ & 70.0 & 9.6 & 22.2 & \multirow[t]{3}{*}{1.6} \\
\hline & $W_{\mathrm{k}}=8.2 \%$ & 71.1 & 8.8 & 23.0 & \\
\hline \multicolumn{2}{|c|}{ Change of color coordinates / Promjena koordinata boje } & 1.1 & -0.8 & 0.8 & \\
\hline 6 & $W_{\mathrm{p}}=73.2 \%$ & 71.2 & 10.3 & 26.0 & \multirow[t]{3}{*}{1.3} \\
\hline & $W_{\mathrm{k}}=8.6 \%$ & 71.9 & 9.6 & 26.8 & \\
\hline \multicolumn{2}{|c|}{ Change of color coordinates / Promjena koordinata boje } & 0.7 & -0.7 & 0.8 & \\
\hline 7 & $W_{\mathrm{p}}=71.8 \%$ & 69.6 & 11.0 & 21.5 & \multirow[t]{3}{*}{1.3} \\
\hline & $W_{\mathrm{k}}=8.4 \%$ & 70.4 & 10.3 & 22.2 & \\
\hline \multicolumn{2}{|c|}{ Change of color coordinates / Promjena koordinata boje } & 0.8 & -0.7 & 0.7 & \\
\hline 8 & $W_{\mathrm{p}}=70.3 \%$ & 68.5 & 11.6 & 24.8 & \multirow[t]{3}{*}{1.5} \\
\hline & $W_{\mathrm{k}}=8.0 \%$ & 69.4 & 10.8 & 25.7 & \\
\hline \multicolumn{2}{|c|}{ Change of color coordinates / Promjena koordinata boje } & 0.9 & -0.8 & 0.9 & \\
\hline
\end{tabular}

Table 5 Evaluation of the quality of dried lumber

Tablica 5. Ocjena kvalitete osušenih piljenica

\begin{tabular}{|l|c|c|c|c|}
\hline Quality characteristics & \multirow{2}{*}{$\begin{array}{c}\text { Sample } \\
\text { Parametri kvalitete }\end{array}$} & \multicolumn{3}{|c|}{ Thickness of lumber / Debljina piljenica } \\
\cline { 3 - 5 } & Uzorak & $h=4 \mathrm{~mm}$ & $h=60 \mathrm{~mm}$ & $h=80 \mathrm{~mm}$ \\
\hline $\begin{array}{l}\text { Difference between average final moisture content and } \\
\text { required moisture content } \\
\text { Razlika između prosječnoga konačnog sadržaja vode } \\
\text { i potrebnog sadržaja vode }\end{array}$ & $W_{0}$ & $0.3 \%$ & $0.4 \%$ & $0.4 \%$ \\
\hline $\begin{array}{l}\text { Range of the final moisture content } \\
\text { Raspon konačnih sadržaja vode }\end{array}$ & & & & \\
\hline $\begin{array}{l}\text { Moisture gradient of lumber } \\
\text { Gradijent vlažnosti piljenica }\end{array}$ & $W_{\mathrm{k} 0}$ & $1.0 \%$ & $1.5 \%$ & $1.3 \%$ \\
\hline
\end{tabular}

Table 6 Technically reasonable norm of the specific heat energy consumption for convective drying of beech lumber according to suggested regimes preserving the natural color of wood

Tablica 6. Tehnički opravdana norma specifične potrošnje toplinske energije za konvektivno sušenje bukovih piljenica prema predloženim režimima sušenja uz očuvanje prirodne boje drva

\begin{tabular}{|c|c|}
\hline $\begin{array}{c}\text { Thickness of dried lumber } \\
\text { Debljina sušenih piljenica }\end{array}$ & $\begin{array}{c}\text { Normative heat energy consumption } \boldsymbol{Q}_{\mathrm{TZN}}, \mathbf{k W h} \cdot \mathbf{m}^{-3} \\
\text { Normativ potrošnje toplinske energije } Q_{\mathrm{TZN}}, \mathrm{kWh} \cdot \mathrm{m}^{-3}\end{array}$ \\
\hline$h=40 \mathrm{~mm}$ & 514.46 \\
\hline$h=60 \mathrm{~mm}$ & 557.62 \\
\hline$h=80 \mathrm{~mm}$ & 643.16 \\
\hline
\end{tabular}


Table 7 Individual items of balance of the specific heat energy consumption used for drying beech lumber with the thickness $h=60 \mathrm{~mm}$ in chamber type KWC 121

Tablica 7. Pojedinačne stavke specifične potrošnje toplinske energije upotrijebljene za sušenje bukovih piljenica debljine $h=60 \mathrm{~mm}$ u sušionici tipa KWC 121

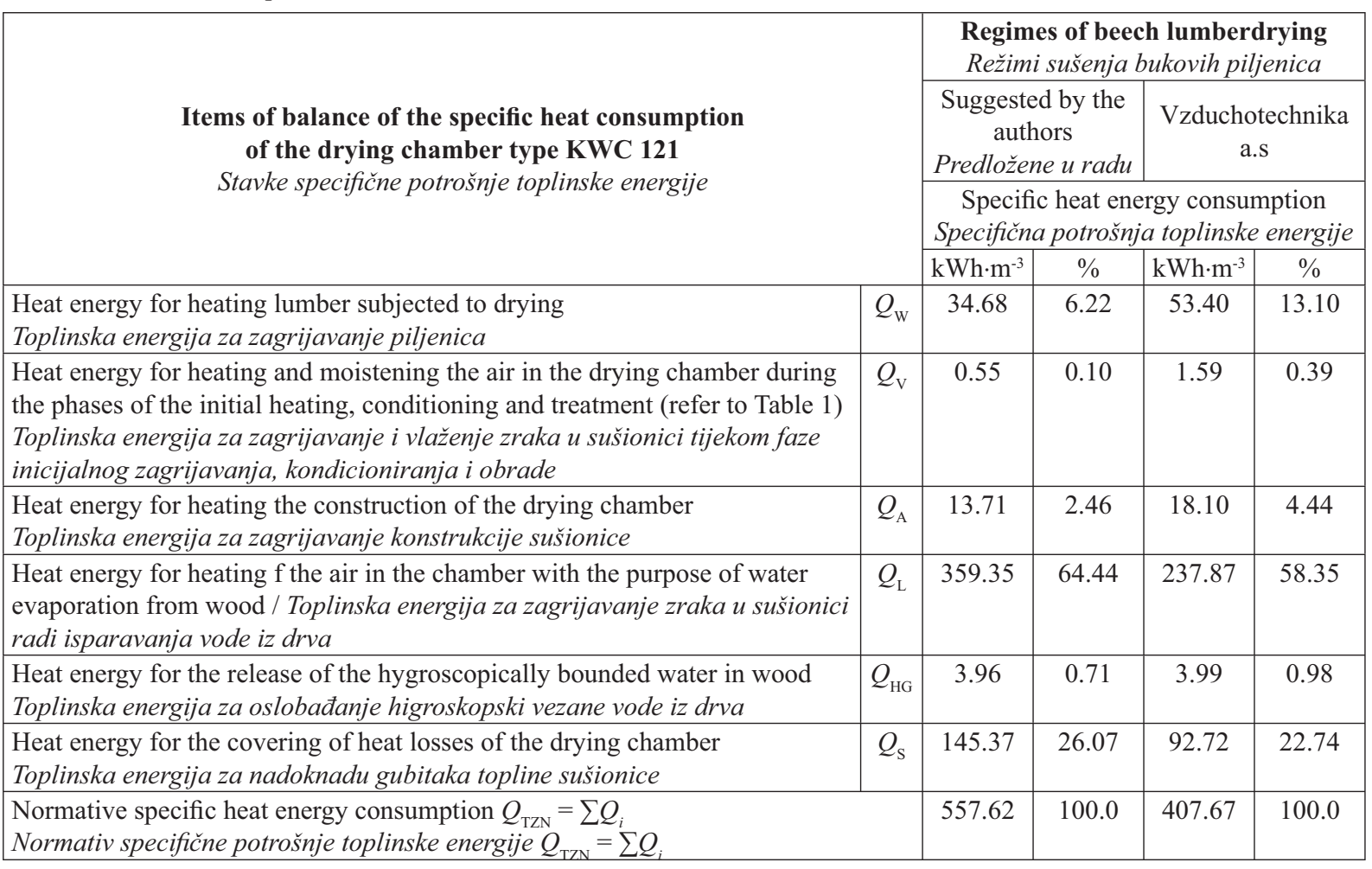

ger time needed for lumber drying. In comparison with the drying regimes of the company Vzduchotechnika a.s. realized at temperatures $t=60 \div 80{ }^{\circ} \mathrm{C}$, the duration of drying beech lumber is 1.9 times longer for the thickness $h=40 \mathrm{~mm}$ while preserving the natural color of wood, 2.3 times longer for the thickness $h=60 \mathrm{~mm}$ and 2.9 times longer for the thickness $h=80 \mathrm{~mm}$. This fact reflects negatively on the use of the capacity of drying chambers, as shown in works by Drahoš and Viktorin (1975), Pervan (2000), Trebula and Klement (2002), Videlov (2003), Dzurenda and Deliiski (2010).

The convective drying of beech lumber in chamber type KWC 121 according to the suggested regimes is characterized by the normative specific heat consumption of $Q_{\mathrm{TZN}}=514.46 \mathrm{kWh} \cdot \mathrm{m}^{-3}$ for lumber with the thickness $h=40 \mathrm{~mm}, Q_{\mathrm{TZN}}=557.62 \mathrm{kWh} \cdot \mathrm{m}^{-3}$ for lumber with the thickness $h=60 \mathrm{~mm}$ and $Q_{\mathrm{TZN}}=643.16$ $\mathrm{kWh} \cdot \mathrm{m}^{-3}$ for lumber with the thickness $\mathrm{h}=80 \mathrm{~mm}$.

Comparing the normative specific heat consumption for lumber with the thickness $h=60 \mathrm{~mm}$ and the normative specific heat energy consumption for drying beech lumber of the same thickness in chamber type KWC 121 according to the regime of the company Vzduchotechnika a.s., whose value is $Q_{\mathrm{TZN}}=557.62$ $\mathrm{kWh} \cdot \mathrm{m}^{-3}$, it has been determined that in the process of drying beech lumber according to the suggested regime, by which the natural color of beech wood is preserved, $26.89 \%$ more heat is consumed. This amount of increased heat energy consumption is caused by the increased heat consumption for heating the air during water evaporation from wood and for covering the heat losses of the drying chamber, due to the prolonged duration of drying.
Comparable results - prolongation of the duration of drying due to the decrease of temperature of the drying medium and the increase of specific heat consumption for drying lumber in drying chambers, can be found in the works of Drahoš and Viktorin (1975), Glijer (1990), Dzurenda (1993), Dzurenda and Deliiski (2004).

\section{CONCLUSION \\ 5. ZAKLJUČAK}

Based on the studies performed, it can be stated that the drying of beech lumber with the thickness $h=$ $40 \mathrm{~mm}, h=60 \mathrm{~mm}$ and $h=80 \mathrm{~mm}$ from moisture content $W_{\mathrm{p}}=70 \%$ to $W_{\mathrm{k}}=8 \%$ in chambers according to the suggested regimes with temperature range of the drying medium $t_{\mathrm{s}}=37 \div 65^{\circ} \mathrm{C}$ causes no changes in the chromophoric structure of wood and that beech wood maintains its natural white-yellow color. The addition of the conditioning phase - partial elimination of moisture gradient during the drying process $(\Delta W=25 \div$ $20 \%$ ) reflects positively on the spreading of moisture content along the section of beech lumber at the end of drying, which enables the grading of this dried lumber into the first quality class.

The negative effect of drying beech wood in the lower part of the temperature range of the classical convective drying regimes is the prolonged drying process. In comparison with the drying regimes of beech lumber of the company Vzduchotechnika a.s. carried out at temperatures $t=60 \div 80{ }^{\circ} \mathrm{C}$, the duration of drying beech lumber with the thickness $h=40 \mathrm{~mm}$ while maintaining the natural color of wood is $2.1 \mathrm{ti}-$ 
mes longer and with the thickness $h=80 \mathrm{~mm}$ it is 2.9 times longer.

The specific heat consumption of beech lumber in chamber type KWC 121 , according to the suggested regimes for drying beech lumber is $Q_{\mathrm{TZN}}=514.46$ $\mathrm{kWh} \cdot \mathrm{m}^{-3}$ for the thickness $h=40 \mathrm{~mm}, Q_{\mathrm{TZN}}=557.62$ $\mathrm{kWh} \cdot \mathrm{m}^{-3}$ for the thickness $h=60 \mathrm{~mm}$ and $Q_{\mathrm{TZN}}=643.16$ $\mathrm{kWh} \cdot \mathrm{m}^{-3}$ for the thickness $h=80 \mathrm{~mm}$. The normative heat consumption used for drying beech lumber with the thickness $h=60 \mathrm{~mm}$ according to the suggested regime is by $26.89 \%$ higher than the specific heat energy consumption used for drying beech lumber with the same thickness according to the regime of the company Vzduchotechnika a.s.

\section{REFERENCES}

\section{LITERATURA}

1. Bučko, J., 1995: Hydrolýzne procesy (Hydrolytical processes). Zvolen. Vydavatel'stvo TU vo Zvolene. $116 \mathrm{~s}$.

2. Colorimetry. 1986: 2nd Edition, CIE Pub. No. 15.2. Commission Internationale de l'Eclairage, Vienna, $74 \mathrm{~s}$.

3. Deliiski, N., 1991: Metod dla ocenki stepeni oblagoraživania bukovych pilomaterialov vo vremja ich propar$\mathrm{ki}$ (Approach for evaluation of the stage of enoblement of beech lumber during steaming). In: Súčasné problémy a perspektívy sušenia bukového reziva. Zvolen. ESVŠLD vo Zvolene, s. 37-44.

4. Deliiski, N., 2003: Modelirane i technologii za proparvane na drveny materiali $\mathrm{v}$ avtoklavi (Modeling and technologies for steaming wood materials in autoclaves). Dissertation for Dr.Sc., University of Forestry, Sofia, $358 \mathrm{~s}$.

5. Deliiski, N.; Dzurenda, L., 2003: Avtomatičeskoe upravlenije procesom konvektivno-kamernoj suški bukovych pilomaterialov s sochraneniem ili c dopustimym izmenenijem ich estestvennoj okraski (Automatic control of the convective drying process of beech lumber in chambers preserving the natural colour of the wood). In: Annals of Warsaw Agricultural University - Forest and Wood Technology 53. s. 42-46.

6. Drahoš, V.; Viktorin, Z., 1975: Souhrn poznatku a výpočtových podkladu $\mathrm{z}$ výskumu sušení a sušáren řeziva.(Summary of knowledge and calculation basis from the research of the drying process and drying kilns). Praha. VÚD, p. 264.

7. Dzurenda, L., 1993: Energetická náročnost' sušenia reziva v malokapacitných komorových sušiarňach. (Energy consumption of drying of sawnwood in smallcapacity kilns). In Sušenie dreva $\mathrm{v}$ malovýrobe. Zvolen: DFTUZVO, p. 97-111.

8. Dzurenda, L; Deliiski, N., 2000: Analysis of moisture content changes in beech wood sleepers in the steaming process with saturated water steam. Wood research. 45: (4) 1-7.

9. Dzurenda, L.; Deliiski, N., 2004: Energetic evaluation of the beech lumber drying regime without color changes of wood mass. In: Trieskové a beztrieskové obrábanie dreva.04'. Zvolen. Vydavatel'stvo Technickej univerzity vo Zvolene, 331-337.

10. Dzurenda, L.; Deliiski, N., 2009: Matematický model výpočtu technicky zdôvodnitel'nej normy spotreby tepla na sušenie reziva $\mathrm{v}$ komorovej sušiarni. (Mathematical model for the calculation of the technical qualification norm of the heat energy consumption for drying of sawnwood in a drying chamber). Acta facultatis xylologiae, 51(2): 49-62.

11. Dzurenda, L.; Deliiski, N., 2010: Tepelné procesy v technológiách spracovania dreva. (Thermal processes in the wood processing technologies). Zvolen, Vydavatel'stvo Technickej univerzity vo Zvolene, p. 274.

12. Glijer, L, 1990: Zužycie energii w suzszarce cyklicznego dzialania do tarcicy. (Use of the energy in the drying chambers). Przemysl drewny 41 (12): 18-20.

13. Halaj, M., 1999: Vplyv hydrotermickej úpravy dreva na zmenu farby bukového dreva. (Influence of the hydrothermal treatment on the change of colour of beech wood). [Dizertačná práca DF - TU Zvolen, Zvolen, 74 p.

14. Kačík, F., 2001: Tvorba a chemické zloženie hydrolyzátov v systéme drevo-voda-teplo. (Creation and chemical composition of hydrolysates in the system woodwater-heat). Zvolen. Vydavatel'stvo TU vo Zvolene. 75 p.

15. Klement, I.; Smilek, P., 2010: Vplyv teploty na proces vysokoteplotného sušenia bukového reziva. (Temperature influence on the process of high temperature drying of beech lumber). Acta facultatis xylologiae, 52 (2): 34-41.

16. Klement, I.; Balkovský, I.; Smilek, P. 2011: Vplyv teploty na proces kontaktného sušenia bukového reziva. (Temperature influence on the process of contact drying of beech lumber). Acta facultatis xylologiae, 53(1):1319.

17. Kollmann, F., 1955: Technologie des Holzes und der Holzwerkstoffe. 2 vyd. Betrlin-Göttingen-Heidelberg Munchen, Speinger - Verlag 1955, 2 zv.

18. Laurova, M.; Mamonova, M.; Kučerova, 2004: Proces parciálnej hydrolýzy bukového dreva (Fagus sylvatica L.) parením a varením. (Process of partial hydrolysis of beech wood (Fagus sylvatica L.) by steaming and cooking). [Vedecké štúdie 2/2004/A], Zvolen, Vydavatel'stvo TU vo Zvolene 2004.

19. Pervan, S., 2000: Priručnik za tehničko sušenie drva. Zagreb, Sand, $272 \mathrm{p}$.

20. Trebula, P., 1989: Hydrotermická úprava a ochrana dreva, čast': Hydrotermická úprava dreva. (Hydro-thermal treatment and protection of wood, part: Hydro-thermal treatment of wood). Zvolen, Vydavatel'stvo Technickej unoiverzity vo Zvolene, $301 \mathrm{p}$.

21. Trebula, P.; Bučko, J., 1996: Vákuové sušnie dreva, technické, technologické a ekologické aspekty. (Vacuum drying of wood, technical, technological and ecological aspects). Vedecké štúdie 5/1996/B,Zvolen, Vydavatel'stvo Technickej univerzity vo Zvolene, $70 \mathrm{p}$.

22. Trebula, P.; Klement, I., 2002: Sušenie a hydrotermická úprava dreva. (Drying and hydro-thermal treatment of the wood) Zvolen. Vydavatel'stvo TU vo Zvolene. $449 \mathrm{p}$.

23. Videlov, Ch., 2003: Sušene i toplino obrabotvane na darvesinata. (Drying and thermal processing of the wood). Sofia, Izdatelska kšta pri LTU. 335 p.

\section{Corresponding address:}

Prof. NENCHO DELIISKI, Dr.Sc., Ph.D.

Faculty of Forest Industry

University of Forestry

10 Kliment Ohridski Blvd.

1756 Sofia, BULGARIA

E-mail: deliiski@netbg.com 